\title{
A water retention model accounting for void ratio changes in double porosity clays
}

\author{
Gema De la Morena ${ }^{1} \cdot$ Vicente Navarro $^{1} \cdot$ Laura Asensio $^{1} \cdot$ Domenico Gallipoli $^{2,3}$ (D)
}

Received: 3 August 2020 / Accepted: 3 December 2020 / Published online: 6 March 2021

(C) The Author(s) 2021

\begin{abstract}
This paper presents a constitutive model that predicts the water retention behaviour of compacted clays with evolving bimodal pore size distributions. In line with previous research, the model differentiates between the water present inside the saturated pores of the clay aggregates (the microstructure) and the water present inside the pores between clay aggregates (the macrostructure). A new formulation is then introduced to account for the effect of the macrostructural porosity changes on the retention behaviour of the soil, which results in a consistent evolution of the air-entry value of suction with volumetric deformations. Data from wetting tests on three different active clays (i.e. MX-80 bentonite, FEBEX bentonite, and Boom clay), subjected to distinct mechanical restraints, were used to formulate, calibrate, and validate the proposed model. Results from free swelling tests were also modelled by using both the proposed double porosity model and a published single porosity model, which confirmed the improvement in the predictions of degree of saturation by the present approach. The proposed retention model might be applied, for example, to the simulation of the hydromechanical behaviour of engineered bentonite barriers in underground nuclear waste repositories, where compacted active clays are subjected to changes of both suction and porosity structure under restrained volume conditions.
\end{abstract}

Keywords Active clays · Double porosity - Degree of saturation · Void ratio - Water retention curve

\section{Introduction}

Compacted active clays are used for the construction of engineered barriers in underground nuclear waste repositories, where they are subjected to complex thermohydromechanical-chemical processes. This includes exposure to wetting from the saturated host rock and drying from the hot nuclear spent fuel [48], which makes the characterisation of the water retention behaviour of these materials particularly important. The water retention behaviour of clays is also relevant to other applications including, for

Domenico Gallipoli

domenico.gallipoli@unige.it

1 Geoenvironmental Group, University of Castilla-La Mancha, Avda. Camilo José Cela S/N, 13071 Ciudad Real, Spain

2 Dipartimento di Ingegneria Civile, Chimica e Ambientale, Università degli Studi di Genova, Via Montallegro 1, 16145 Genova, Italy

3 Laboratoire SIAME, Université de Pau et des Pays de l'Adour, Allée du Parc Montaury, 64600 Anglet, France example, the prediction of settlements under superficial foundations, the study of groundwater flow and the design of agricultural irrigation systems [3, 44, 69].

Early retention models have proposed a unique relationship between degree of saturation and suction, thus disregarding the effect of porosity on soil water content (e.g. $[3,15,70])$. Nevertheless, experiments published in the literature (e.g. [51-53, 62, 74]) have shown that changes in pore volume can significantly influence the water retention behaviour of the soil. In this sense, the effect of stress level and volume change and, in particular, the influence of the change in soil pore size distribution on the water retention of soils have also been studied [54, 68]. Subsequent models have, therefore, introduced an additional dependency of degree of saturation on void ratio without, however, considering the different structural levels of double porosity clays [16-18, 27, 37, 45, 57, 65, 67]. For instance, in the study developed by Huyghe et al. [22], the soil water retention equation proposed takes into account the soil volume deformation, establishing its relationship with the 
Table 1 Properties of MX-80 bentonite [28], FEBEX bentonite [14] and Boom clay $[51,53,60]$

\begin{tabular}{|c|c|c|c|}
\hline & MX-80 & FEBEX & Boom clay \\
\hline \multicolumn{4}{|c|}{ Chemical composition (weight \%) } \\
\hline $\mathrm{SiO}_{2}$ & 59.82 & 58.71 & 57.58 \\
\hline $\mathrm{Al}_{2} \mathrm{O}_{3}$ & 21.27 & 17.99 & 12.93 \\
\hline $\mathrm{Fe}_{2} \mathrm{O}_{3}$ & 3.62 & 3.13 & 7.57 \\
\hline $\mathrm{Na}_{2} \mathrm{O}$ & 2.86 & 1.31 & 0.12 \\
\hline $\mathrm{MgO}$ & 2.77 & 4.21 & 2.40 \\
\hline $\mathrm{CaO}$ & 1.49 & 1.83 & 2.22 \\
\hline $\mathrm{K}_{2} \mathrm{O}$ & 0.55 & 1.04 & 1.96 \\
\hline $\mathrm{FeO}$ & 0.49 & - & - \\
\hline $\mathrm{TiO}_{2}$ & 0.15 & 0.23 & 0.88 \\
\hline $\mathrm{MnO}$ & - & 0.04 & 0.01 \\
\hline $\mathrm{P}_{2} \mathrm{O}_{5}$ & - & 0.02 & 0.18 \\
\hline \multicolumn{4}{|c|}{$\begin{array}{l}\text { Mineralogical composition (weight } \\
\% \text { ) }\end{array}$} \\
\hline Smectite & 87.6 & 92 & $10-20$ \\
\hline Plagioclase & 4.2 & 2 & $<5$ \\
\hline Quartz & 4.1 & 2 & $15-25$ \\
\hline K-feldspar & 1.8 & - & $<5$ \\
\hline Rutile & 0.9 & - & - \\
\hline Calcite & 0.6 & - & $<5$ \\
\hline Pyrite & 0.6 & - & $<5$ \\
\hline Illite & 0.1 & - & $20-30$ \\
\hline Kaolinite & - & - & $20-30$ \\
\hline Cristobalite & - & 2 & - \\
\hline \multicolumn{4}{|l|}{ Other properties } \\
\hline CEC (eq/kg) & 0.84 & 1.02 & 0.3 \\
\hline $\begin{array}{c}\mathrm{Na}^{+} / \mathrm{K}^{+} / \mathrm{Ca}^{2+} / \\
\mathrm{Mg}^{2+}(\mathrm{eq} / \mathrm{kg})\end{array}$ & $\begin{array}{r}0.58 / 0.02 / \\
0.25 / 0.08\end{array}$ & $\begin{array}{r}0.25 / 0.02 / \\
0.42 / 0.32\end{array}$ & $\begin{array}{r}0.087 / 0.023 / \\
0.038 / 0.037\end{array}$ \\
\hline $\begin{array}{l}\text { Mineral density } \\
\left(\mathrm{kg} / \mathrm{m}^{3}\right)\end{array}$ & 2780 & 2700 & 2700 \\
\hline Liquid limit & 510 & 102 & 56 \\
\hline Plastic limit & 50 & 53 & 29 \\
\hline $\begin{array}{l}\text { Specific surface } \\
\left(\mathrm{m}^{2} / \mathrm{g}\right)\end{array}$ & 632 & 725 & 53 \\
\hline
\end{tabular}

mechanical behaviour (i.e. the effective stress) from a mixture theory standpoint.

Two distinct porosity structures [19] have been experimentally observed in compacted clays, namely a microstructural porosity corresponding to the intra-aggregate voids and a macrostructural porosity corresponding to the inter-aggregate voids $[6,7,52,53]$. Consistent with these observations, several models have been proposed to incorporate the effects of double porosity on the mechanical behaviour of compacted clays (e.g. [1, 20, 38, 42, 59]).

Only recently, some authors have, however, started to analyse the effects of porosity structure on soil-water retention and have proposed suitable modelling strategies that can account for the evolution of pore size distribution (e.g. [8-11, 23]). In this context, the present paper proposes a new approach to describe the influence of double porosity on soil-water retention. This approach combines the formulations of Navarro et al. [40] and De la Morena et al. [5] for separating microstructural and macrostructural water contents with a retention law that describes the effect of macrostructural volume changes on degree of saturation. This macrostructural retention law consists of an adaptation of a previous formulation proposed by Gallipoli et al. $[17,18]$ for single porosity soils.

The resulting model has been validated against a comprehensive set of experimental data from free swelling, constant load and confined (constant volume) wetting tests on three different active clays, i.e. MX-80 bentonite, FEBEX bentonite, and Boom clay. The main characteristics of these three clays and the relevant experimental procedures are summarised in the first part of the paper, followed by the description of the proposed retention model. Comparison between experiments and model simulations confirms that the incorporation of volumetric deformation inside a double porosity framework can improve the prediction of degree of saturation in compacted clays.

\section{Materials and methods}

Table 1 illustrates the main properties of MX-80 bentonite, FEBEX bentonite, and Boom clay. Retention tests on compacted samples of these three materials have been performed by a number of authors as listed in Tables 2, 3, and 4 . In these tests, the samples were compacted and subsequently subjected to monotonic wetting with deionised water under free swelling, constant load or confined (constant volume) conditions. Since the initial water content was very low, the main wetting curve was assumed to be followed. The vapour equilibrium technique, consisting in the imposition of known levels of relative humidity to the sample, was generally employed to control suctions higher than 2-3 MPa (e.g. Romero [51]). Membrane cells or pressure plates) were usually employed to control suctions below 2-3 MPa. The samples analysed were not fully saturated in any case during the tests.

Figure 1 shows the changes in water content recorded during free swelling and constant load wetting tests on MX-80 bentonite, FEBEX bentonite, and Boom clay (Tables 2 and 3). In these tests, volumetric strains were recorded throughout wetting, which allowed the measurement of void ratio in addition to water content. This is important for the calibration and validation of the proposed model, which, in contrast to the model previously proposed 
Table 2 Free swelling tests on MX-80 bentonite, FEBEX bentonite, and Boom clay

\begin{tabular}{ll}
\hline Reference & Initial dry densities $\left(\mathrm{kg} / \mathrm{m}^{3}\right)$ \\
\hline MX-80 bentonite & \\
Dieudonné et al. [11] & 2040 \\
Likos and Lu [31] & 1570 \\
Likos and Wayllace [32] & $1220,1320,1480$ \\
Saiyouri et al. [55] & 1750 \\
FEBEX bentonite & 1670,1760 \\
Lloret and Villar [33] & 1670 \\
Lloret et al. [34] & 1580,1690 \\
Pintado [47] & $1670(2$ tests $), 1710,1720,17501760,1810$ \\
Villar [72] & 1650 \\
Villar [73] & \\
Boom clay & $1440,1540,1600,1680,1770,1860,1920$ \\
Romero [51] & $1400(2$ tests $)$ \\
Romero et al. [52] & 1750 \\
Salager et al. [56] & \\
\hline
\end{tabular}

Table 3 Constant load wetting tests on Boom clay

\begin{tabular}{llc}
\hline Reference & $\begin{array}{l}\text { Initial dry } \\
\text { densities }\left(\mathrm{kg} / \mathrm{m}^{3}\right)\end{array}$ & Vertical load (MPa) \\
\hline Romero [51] & 1670 & $\begin{array}{c}0.026(2 \text { tests }), 0.085 \\
(4 \text { tests }), 0.3,0.55\end{array}$ \\
& 1370 & $0.085,0.3,0.6(5$ tests $)$ \\
\hline
\end{tabular}

by Navarro et al. [40], includes the effect of the void ratio variation on the retention behaviour.

Figure 2 shows the changes in water content recorded during confined (constant volume) wetting tests on MX-80 bentonite, FEBEX bentonite, and Boom clay (Table 4). In these tests, wetting occurred at constant void ratio as the deformation of the specimen was prevented.

\section{Model description}

The proposed retention model is based on the double porosity concept by Gens and Alonso [19]. In this framework, as mentioned in Introduction, two structural levels are differentiated: the microstructure, which is associated with the voids inside the aggregates of clay particles, and the macrostructure, related to the space between the aggregates ([30, 61]; among others). Different authors (e.g. $[46,52,53,74])$ have suggested that, at high suction levels, virtually all water is adsorbed inside the micropores, and the presence of free water in the soil macropores is negligible. Therefore, over this suction level, defined as $s_{\text {Mlim }}$, the microstructural water content $w_{\mathrm{m}}$ is assumed to coincide with the total water content $w$ of the soil $[52,74]$. For this reason, if the microstructural water is considered to occupy the whole microstructural pore space (see, for example, $[1,7,77])$, the microstructural void ratio $e_{\mathrm{m}}$ (microstructural pore volume per mineral volume) can be calculated over this suction range as:

$e_{\mathrm{m}}=G_{\mathrm{S}} w_{\mathrm{m}}=G_{\mathrm{S}} w$

where $G_{\mathrm{S}}$ is the specific gravity of the soil particles. Navarro et al. [40] and De la Morena et al. [5] applied this equation to obtain the values of $e_{\mathrm{m}}$ associated with different values of the thermodynamic swelling pressure $\pi$ [35], which, in equilibrium between microstructural water and a low-salinity macrostructural aqueous solution can be defined as [42]:

$\pi=p+s_{\mathrm{M}}$

where $p$ is the mean net stress, defined as the difference between the external mean stress $p_{\mathrm{TO}}$ and the pore gas pressure $P_{\mathrm{G}}$, and $s_{\mathrm{M}}$ is the macrostructural matric suction, identified with the capillary suction: $P_{\mathrm{G}}$ minus the liquid pressure $P_{\mathrm{L}}$. Navarro et al. [41] demonstrated that $\pi$ controls the change in $e_{\mathrm{m}}$, and therefore $\pi$ can be understood as a microstructural effective stress. In addition, this expression agrees with the expression found by Borja and Choo [2] to define the microstructural effective stress. For monotonic hydration paths, $e_{\mathrm{m}}$ and $\pi$ are related through a state surface as that defined by Navarro et al. [40] and De la Morena et al. [5]. The problem when characterising this surface arises when Eq. (1) is no longer valid, and the experimental values of $w$ are associated with both $w_{\mathrm{m}}$ and the macrostructural water content $w_{\mathrm{M}}$. This happens when $s_{\mathrm{M}}$ is close to $s_{\mathrm{Mlim}}$, and water starts to fill the macropores. 
Table 4 Confined (constant volume) wetting tests on MX-80 bentonite, FEBEX bentonite, and Boom clay

\begin{tabular}{ll}
\hline Reference & Dry densities $\left(\mathrm{kg} / \mathrm{m}^{3}\right)$ \\
\hline MX-80 bentonite & \\
Delage et al. [7] & 1700 \\
Jacinto [24] & 1600 \\
Jacinto et al. [25] & 1600,1750 \\
Kuusela-Lahtinen et al. [29] & 1600,1700 \\
Man and Martino [36] & $1500,1600,1700,1800$ \\
Pintado et al. [49] & $1500,1600,1610,1700$ \\
Seiphoori et al. [62] & $1530,1685,1830$ \\
Tang and Cui [66] & $1650,1700,1820$ \\
Villar [73] & $1430-1730$ \\
Villar [74] & 1600 \\
FEBEX bentonite & \\
Jacinto et al. [26] & 1600,1650 \\
Lloret and Villar [33] & $1600,1650,1700$ \\
Lloret et al. [34] & $1600,1650,1700$ \\
Pintado [47] & $1590,1650,1710$ \\
Vaunat and Gens [71] & 1590 \\
Villar [72] & 1580,1590 \\
Villar [73] & $1600,1650,1700$ \\
Villar [74] & $1500,1600,1700$ \\
Villar et al. [75] & $1550,1600,1650,1700$ \\
Boom clay & 1400,1660 \\
Della Vecchia et al. [9] & 1740 \\
Della Vecchia et al. [8] & $1400,1500,1600,1700$ \\
Hu et al. [21] & 1370,1670 \\
Romero [51] & 1370,1670 \\
Romero et al. [53] & 1400,1640 \\
Romero et al. [52] & \\
\hline
\end{tabular}

The value of $s_{\text {Mlim }}$ has been studied for different active clays. For example, Romero et al. [53] performed Mercury Intrusion Porosimetry (MIP) tests on Boom clay concluding that a suction of $2 \mathrm{MPa}$ marks the onset of water flooding in the inter-aggregate pores. Similarly, Or and Tuller [46] indicated that the amount of free capillary water becomes negligible at suctions greater than $10 \mathrm{MPa}$ for different soils. In another work on MX-80 bentonites, Jacinto et al. [25] found that dry density influences the retention behaviour only for suctions smaller than $30 \mathrm{MPa}$, which corresponds to the lower limit of the suction range dominated by adsorptive storage mechanisms [52]. In a similar work on MX-80 bentonite, Villar [74] found instead that water occupies only the soil micropores for suctions larger than $10 \mathrm{MPa}$. The results by Jacinto et al. [25] and Villar [74] indicate that, for MX-80 bentonites, the suction threshold marking flooding of macropores can vary between 10 and $30 \mathrm{MPa}$. In any case, these values are below $50 \mathrm{MPa}$, which, according to the psychrometric law
[13], at $20{ }^{\circ} \mathrm{C}$, is associated with a relative humidity of $70 \%$. This value is proposed by Cases et al. [4] and Woodruff and Revil [76] to differentiate crystalline hydration from hydration associated with double-layer processes. Therefore, in wetting processes, until $s_{\text {Mlim }}$ is reached, there will be a nonnegligible range of water retention behaviour associated with double-layer processes. If, in that range of suctions, a logarithmic law is adopted to define it [12], the increase in microstructural void ratio, $\Delta e_{\mathrm{m}}$, can be calculated as:

$\Delta e_{\mathrm{m}}=-\kappa_{\mathrm{m}} \operatorname{Ln}\left(\frac{\pi+P_{\mathrm{ATM}}}{\pi_{\mathrm{ref}}+P_{\mathrm{ATM}}}\right)$

where $\pi_{\mathrm{m}}$ can be understood as the microstructural stiffness and $P_{\mathrm{ATM}}$ is the atmospheric pressure. Any value of $\pi$ can be considered as a reference $\pi_{\text {ref }}$, in particular, the $50 \mathrm{MPa}$ mentioned above. Navarro et al. [40] and De la Morena et al. [5] verified the capacity of Eq. (3) to approximate the state surface $e_{\mathrm{m}}-\pi$ for $\pi$ values lower than $50 \mathrm{MPa}$, which is applied in the present work. Experimental values associated with decreasing suction are progressively incorporated into the analysis, estimating the value of $\kappa_{\mathrm{m}}$. When $w_{\mathrm{M}}$ becomes relevant, Eq. (1) is no longer valid, and $e_{\mathrm{m}}$ cannot be estimated directly from $w$, since $w=w_{\mathrm{m}}+w_{\mathrm{M}}$. Therefore, $\kappa_{\mathrm{m}}$ can no longer directly relate $\pi$ to water content, since an increment in water content in both $e_{\mathrm{m}}$ and $e_{\mathrm{M}}$ occurs, and the quality of the estimation is reduced. Thus, $s_{\text {Mlim }}$ is identified as the value of suction from which macrostructural water starts to be relevant.

For lower values of suction, $w_{\mathrm{M}}$ and $w_{\mathrm{m}}$ are differentiated assuming that the $\kappa_{\mathrm{m}}$ value identified for higher suction allows to estimate $e_{\mathrm{m}}$ (Eq. (3)) and, consequently, $w_{\mathrm{m}}$ (Eq. (1)). In this way, the experimental water content data, which include both macrostructural and microstructural water content, are higher than the estimated $w_{\mathrm{m}}$ values. Therefore, from the experimental values of $w, w_{\mathrm{M}}$ is calculated as:

$w_{\mathrm{M}}=w-w_{\mathrm{m}}$

Navarro et al. [40] and De la Morena et al. [5] showed the consistency of this procedure for MX-80 bentonite. However, it is interesting to assess its scope for a wider range of clays. This is done in the following section. In addition, as explained in Introduction, it is of great interest to include in the analysis the effect of the variation in the void ratio on the soil retention behaviour. For this purpose, the formulation proposed by Gallipoli et al. [17, 18] and Gallipoli [16] for a single porosity retention model (SPRM) is taken as a reference model: 


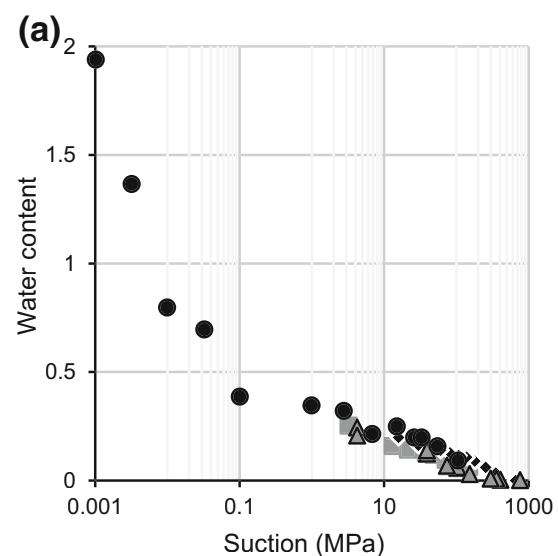

aDieudonne et al. (2016) Likos and Lu (2006)

$\Delta$ Likos and Wayllace (2010) $\quad$ Saiyouri et al. (2004) (b) 0 .

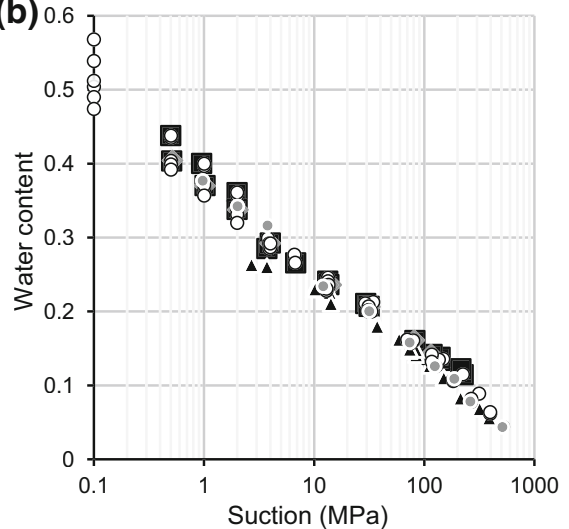

- Lloret and Villar (2007) $\quad$ Lloret et al. (2003) . Pintado (2002) OVillar (2002) - Villar (2004)

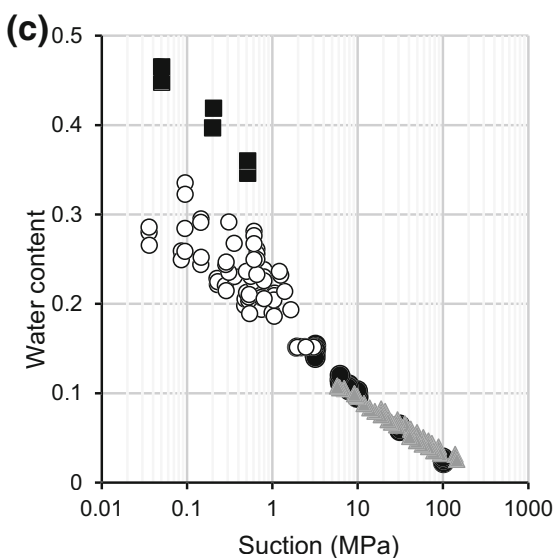

-Romero (1999) free swelling oRomero (1999) constant load $\triangle$ Romero et al. (2011) - Salager et al. (2011)

Fig. 1 Free swelling and constant load wetting tests on a MX-80 bentonite, b FEBEX bentonite and $\mathbf{c}$ Boom clay

(a)

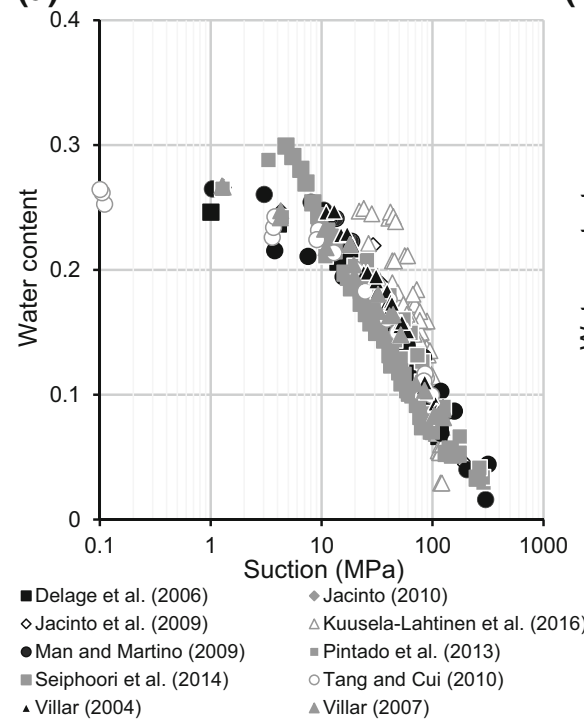

(b)

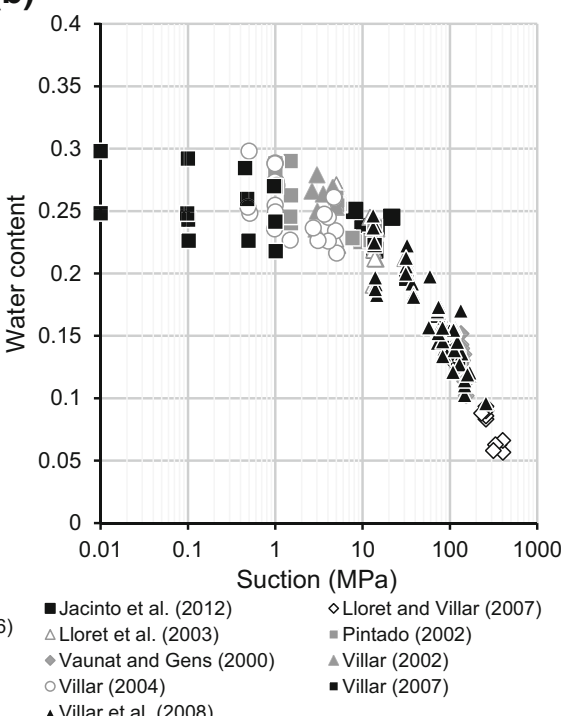

(c)

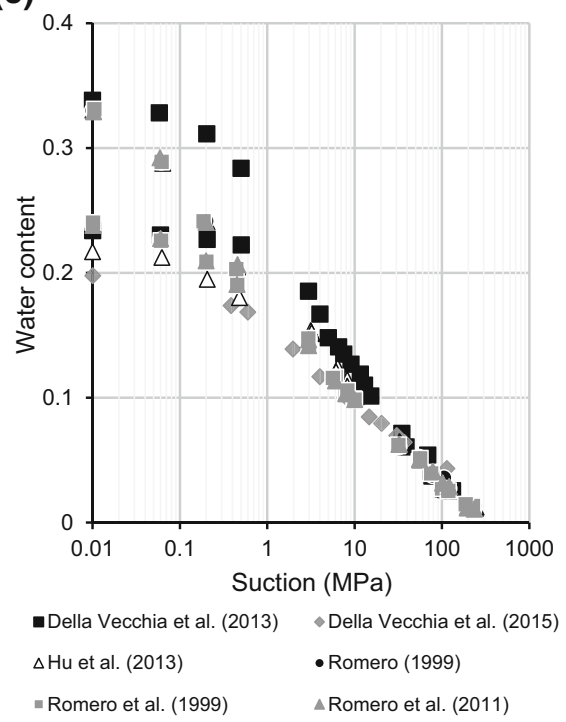

Fig. 2 Confined (constant volume) wetting tests on a MX-80 bentonite, b FEBEX bentonite and $\mathbf{c}$ Boom clay

$S r_{\mathrm{SPRM}}=\left[1+\left(s \frac{e^{1 / \lambda_{\mathrm{s}}}}{\beta}\right)^{\lambda_{\mathrm{s}} / m}\right]^{-m}$

where $S r_{\mathrm{SPRM}}$ is the degree of saturation computed with the model, $s$ is the suction, $e$ is the total void ratio ( $e=e_{\mathrm{M}}+e_{\mathrm{m}}$, being $e_{\mathrm{M}}$ the macrostructural void ratio or macrostructural pore volume per mineral volume), and $\lambda_{\mathrm{s}}$, $\beta$ and $m$ are material parameters. It is important to note that this model is thermodynamically consistent, as explained by Song and Borja [63]. If the model is expanded to a double porosity system, it seems reasonable to introduce the effect of the variation in the void ratio in $S r_{\mathrm{M}}$ (macrostructural degree of saturation), and to do so using the macrostructural void ratio:
$S r_{\mathrm{M}}=\left[1+\left(s_{\mathrm{M}} \frac{e_{\mathrm{M}}^{1 / \lambda_{s, \mathrm{M}}}}{\beta_{\mathrm{M}}}\right)^{\lambda_{\mathrm{s}, \mathrm{M}} / m_{\mathrm{M}}}\right]^{-m_{\mathrm{M}}}$

where $\lambda_{\mathrm{s}, \mathrm{M}}, \beta_{\mathrm{M}}$, and $m_{\mathrm{M}}$ are macrostructural material parameters. Since $S r_{M}$ (i.e. $w_{M}$ ) is relevant for nonnegligible suction ( $s_{\mathrm{Mlim}}$ not lower than $2 \mathrm{MPa}$ ), a nonnegligible variation in the void ratio can be expected in unconfined conditions. This variation will be mainly due to $e_{\mathrm{M}}$, since, as shown by Navarro et al. [40] and De la Morena et al. [5] (and will be illustrated in the next section), the variation in $e_{\mathrm{m}}$ is not relevant for these suctions. Therefore, Eq. (6) represents a significant improvement with respect to the previously cited works. In addition, unlike other proposals 

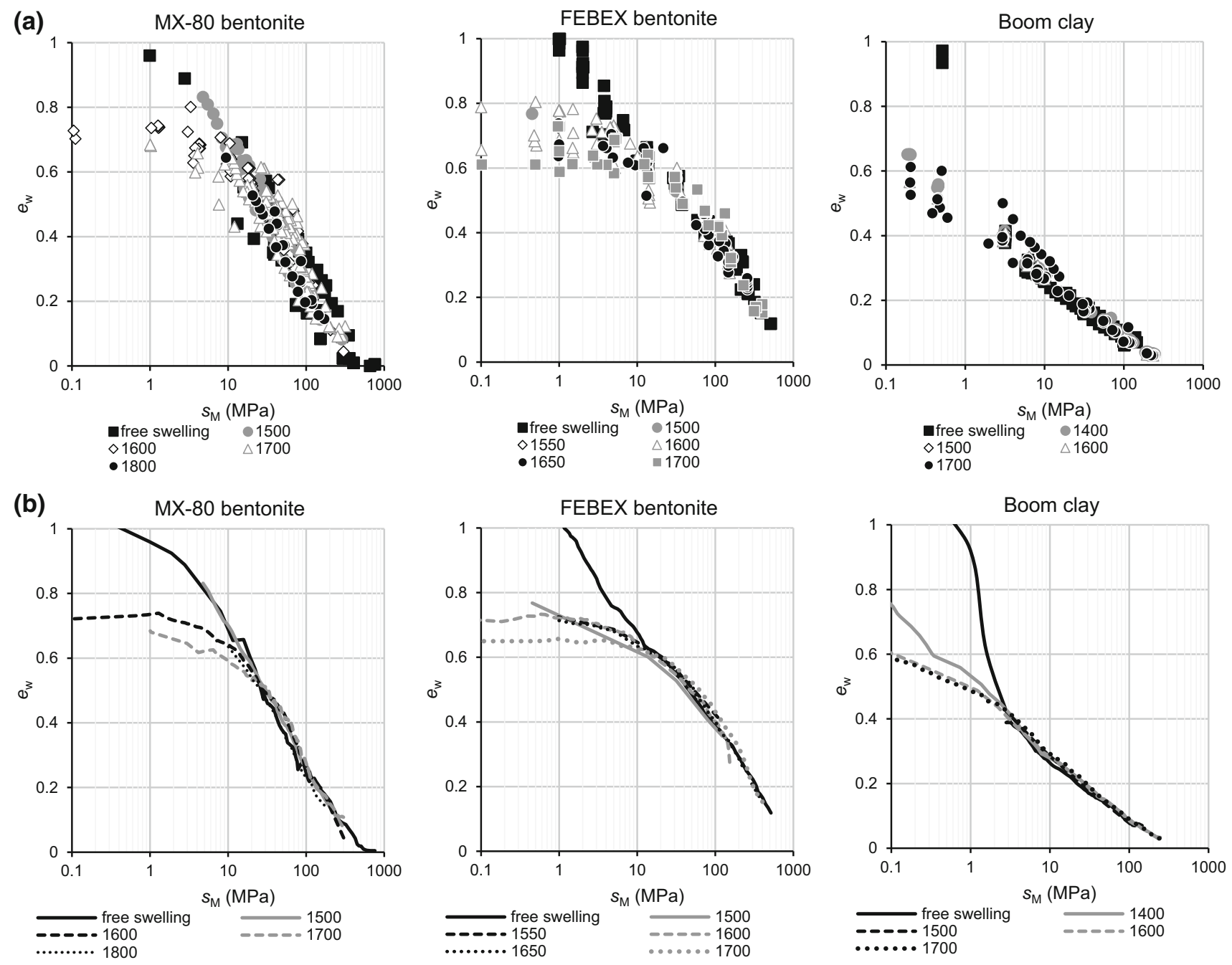

Fig. 3 a Experimental data from free swelling and confined wetting tests at different dry densities. b Mean curves of free swelling and confined wetting tests at different dry densities

(e.g. $[8-10,23])$, the presence of air in the intra-aggregate is neglected (a hypothesis accepted and used by, e.g., $[1,7,77])$. Therefore, the microstructural strain model is directly related to the evolution of the microstructural water content, and additional parameters are not necessary to describe the microstructural water retention model.

Finally, the full double porosity retention model (DPRM) combines the above microstructural and macrostructural models to calculate the overall degree of saturation $S r_{\text {DPRM }}$ of the soil according to the following equation:

$S r_{\mathrm{DPRM}}=\frac{S r_{\mathrm{M}} e_{M}+e_{\mathrm{m}}}{e}$

\section{Model calibration}

This section presents the calibration of the proposed retention model against wetting tests on MX-80 bentonite, FEBEX bentonite, and Boom clay. The limiting value of macrostructural suction $s_{\text {Mlim }}$, which marks the onset of macrostructural flooding, was first determined from free swelling and confined wetting tests. To this end, the experimental values of water ratio $e_{\mathrm{w}}$ (volume of water per volume of mineral) against the corresponding values of macrostructural suction $s_{\mathrm{M}}$ for different tests at different dry densities have been plotted. These curves should overlap when $s_{\mathrm{M}}$ is greater than $s_{\mathrm{Mlim}}$ since, in this case, all pore water exists inside the soil microstructure, whose retention behaviour depends only on the microstructural effective stress. The same curves should, however, start to diverge when $s_{\mathrm{M}}$ becomes smaller than $s_{\text {Mlim }}$ as water starts to flood the soil macrostructure, whose retention behaviour 
Table 5 Values of $\pi_{\lim }$ for the three clays considered in the present study

\begin{tabular}{ll}
\hline Clay & $\pi_{\lim }(\mathrm{MPa})$ \\
\hline MX-80 bentonite & 20 \\
FEBEX bentonite & 10 \\
Boom clay & 2 \\
\hline
\end{tabular}

depends also on dry density due to the link between the macrostructural degree of saturation $S r_{\mathrm{M}}$ and void ratio $e_{\mathrm{M}}$, see Eq. (6).

Figure 3a shows the experimental values of water ratio $e_{\mathrm{w}}$ plotted against the macrostructural suction $s_{\mathrm{M}}$ for free swelling and confined wetting tests at different dry densities on the three materials considered in the present study (Tables 2 and 4). Inspection of Fig. 3a indicates that, given the large scatter of data, it is not easy to identify the point where the experimental curves start to diverge. For that reason, the mean curve of each experiment was calculated using a centred moving average method [39], see Fig. 3b. To calculate the suction in which the mean curves start to diverge, a statistical analysis of the data in Fig. $3 b$ was carried out. In this way, the values of $s_{\text {Mlim }}$ were obtained as those for which the water ratios start to differ more than a $5 \%$. This analysis leads to $s_{\text {Mlim }}$ values equal to 20,10 and $2 \mathrm{MPa}$ for MX-80 bentonite, FEBEX bentonite, and Boom clay, respectively. These results are consistent with the values obtained in previous studies of the same materials (see Sect. 3).

The limits obtained from Fig. 3 can be transformed in terms of microstructural effective stress by means of Eq. (2). For free swelling tests, since the confinement is null during the tests, the mean net stress $p$ can be assumed to be almost zero. Therefore, without salinity effects, the value of the macrostructural suction $s_{\text {Mlim }}$ is equal to the microstructural effective stress $\pi_{\mathrm{lim}}$. For confined tests, the swelling pressure developed for the higher suctions (far from saturation) can be considered low and therefore negligible compared with $s_{\mathrm{M}}$. In this way, it can be assumed that $\pi_{\lim }$ is roughly the same as $s_{\text {Mlim }}$ in the three active clays studied. The values of $\pi_{\lim }$ are reported in Table 5. It should be noted that, as expected, the value of $\pi_{\lim }$ depends on the clay nature and, in particular, on the clay mineralogy $[43,50,64]$, but also on the type of exchangeable cations $[4,32,58]$.

Once the value of $\pi_{\mathrm{lim}}$ was determined, the state surfaces defined by Navarro et al. [40] and De la Morena et al. [5] were obtained using the results from free swelling tests in Table 2 limited to the range where $\pi$ is greater than $\pi_{\text {lim }}$. As stated in Sect. 3, for the range in which the hydration associated with double-layer processes is not negligible,
Table 6 Values of $\pi_{\mathrm{m}}$ for MX-80 bentonite, FEBEX bentonite, and Boom clay

\begin{tabular}{ll}
\hline Clay & $\pi_{\mathrm{m}}$ \\
\hline MX-80 bentonite & 0.040 \\
FEBEX bentonite & 0.067 \\
Boom clay & 0.064 \\
\hline
\end{tabular}

the increase in microstructural void ratio is calculated using Eq. (3). As noted, in free swelling tests $\pi$ coincides with $s_{\mathrm{M}}$. The values of $\pi_{\mathrm{m}}$ and the obtained state surfaces are shown in Table 6 and in Fig. 4, respectively, for the three active clays studied. As expected, inspection of Fig. 4 indicates that, when the microstructural effective stress $\pi$ is lower than $\pi_{\text {lim }}$, the water content is higher than the value predicted by the microstructural model due to the presence of macrostructural water.

Next, the parameter values of the macrostructural retention model were determined by fitting Eq. (6) to data from: (a) free swelling tests by Dieudonné et al. [11], Likos and $\mathrm{Lu}$ [31], Likos and Wayllace [32] and Saiyouri et al. [55] for MX-80 bentonite, (b) free swelling tests by Villar [52] for FEBEX bentonite, and (c) free swelling tests by Salager et al. [57] and constant load test (at constant vertical loads of $0.026,0.55$ and $0.6 \mathrm{MPa}$ ) by Romero [51] for Boom clay. Confined tests were not considered in this stage since the experimental values of the net mean stress developed during the tests were not available, and $\pi$ could not be calculated. In each test, the value of $e_{\mathrm{m}}$ was computed with the microstructural model using the parameter values in Table 6. Moreover, Eq. (7) was employed to determine the experimental values of the macrostructural degree of saturation $\mathrm{Sr}_{\mathrm{M}}$. To simplify graphical representation of the data, Eq. (6) is rewritten in the following form [17]:

$S r_{\mathrm{M}}=\left[1+\left(\frac{\bar{s}_{\mathrm{M}}}{\beta_{\mathrm{M}}}\right)^{\lambda_{s, \mathrm{M}} / m_{\mathrm{M}}}\right]^{-m_{\mathrm{M}}}$

where ${ }^{-}{ }_{\mathrm{M}}$ is the scaled macrostructural suction defined as:

$\bar{s}_{\mathrm{M}}=s_{\mathrm{M}} e_{\mathrm{M}}^{1 / \hat{\mathrm{i}}_{\mathrm{M}}}$

In this way, since $S r_{\mathrm{M}}$ is considered to depend on two independent variables (i.e. macrostructural suction and void ratio), the three-dimensional fit of Eq. (6) in the $\left(S r_{\mathrm{M}}-s_{\mathrm{M}}-e_{\mathrm{M}}\right)$ space is recast as a two-dimensional fit of Eq. (8) in the $\left(S r_{\mathrm{M}^{-}}{ }^{-}{ }_{\mathrm{M}}\right)$ plane, see Fig. 5a. Therefore, the model can be represented as a $2 \mathrm{D}$ curve.

For comparison, the single porosity retention model of Gallipoli et al. [17], Eq. (5), was also calibrated against the same experimental data, in Fig. 5b. Also in this case, the 
(a)

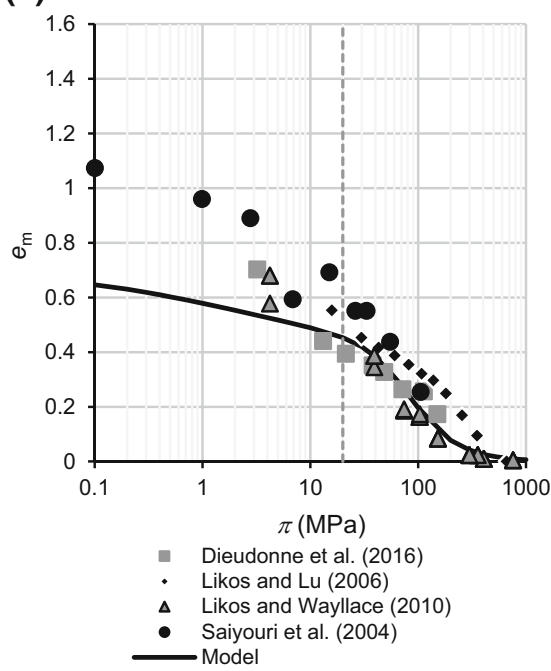

(b)

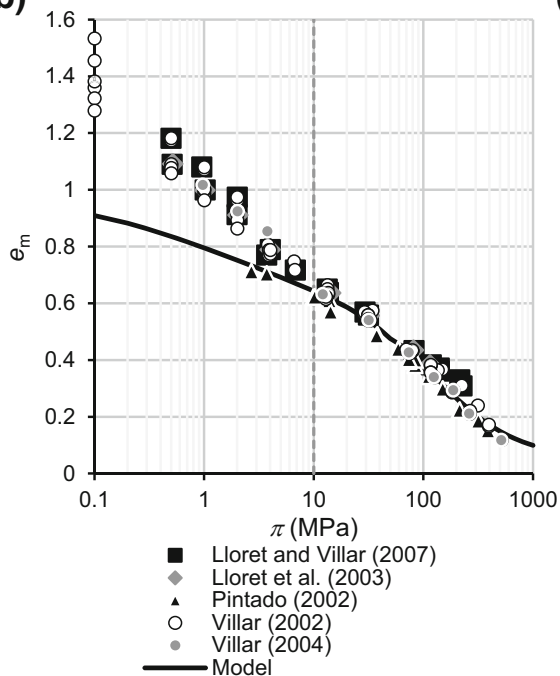

(c)

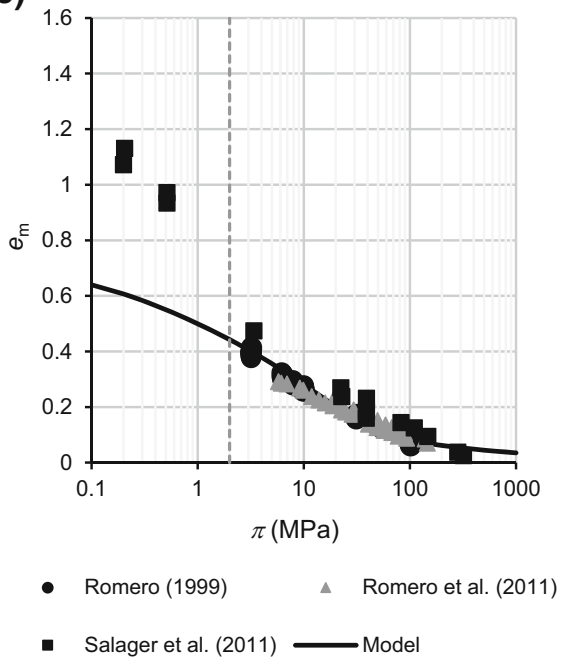

Fig. 4 Fitting of microstructural model to data for a MX-80 bentonite, $\mathbf{b}$ FEBEX bentonite and $\mathbf{c}$ Boom clay. The dashed lines represent the corresponding values of $\pi_{\mathrm{lim}}$
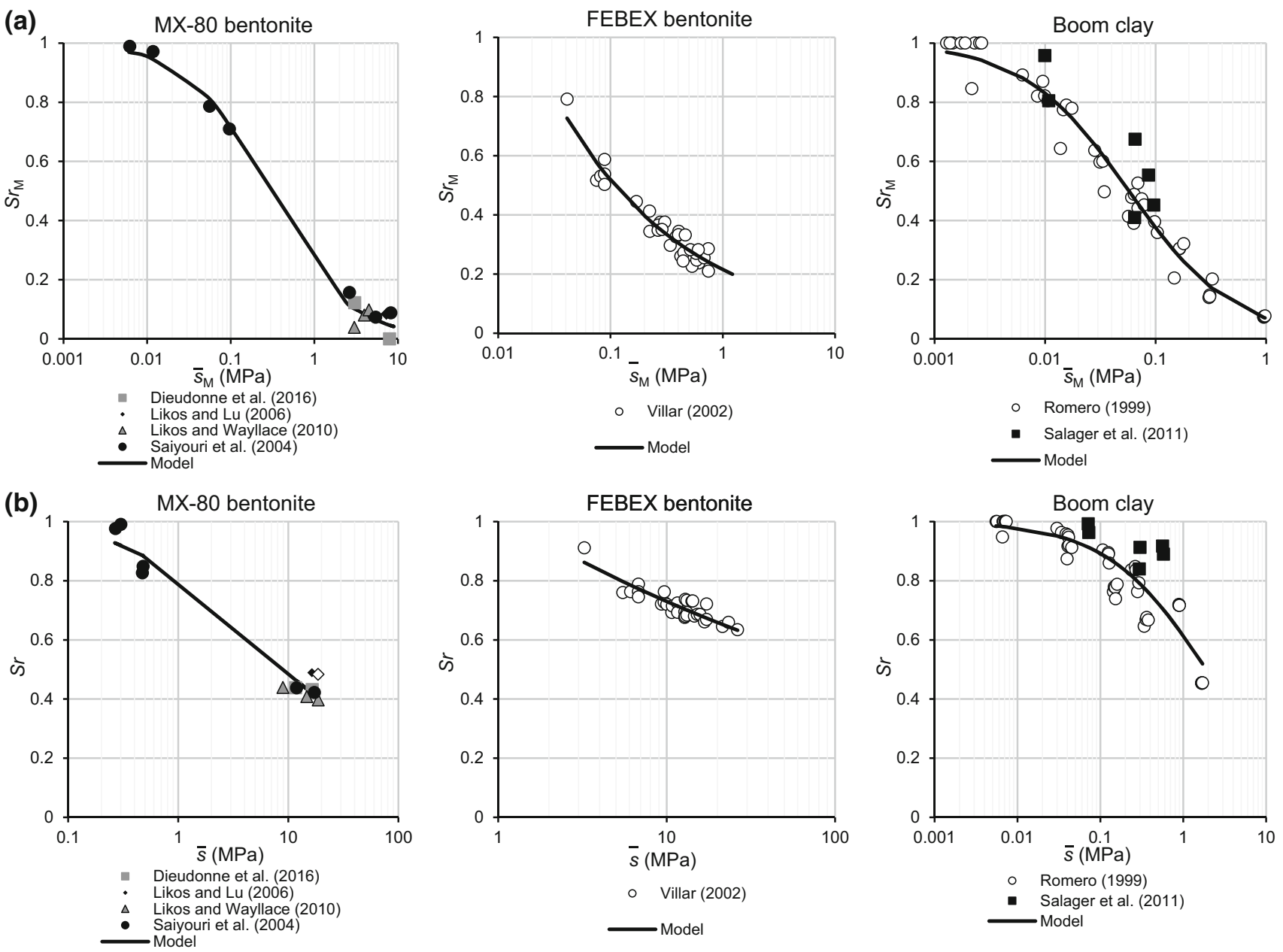

Fig. 5 a Fitting of macrostructural retention model to experimental data of MX-80 bentonite, FEBEX bentonite, and Boom clay. b Fitting of single porosity retention model to experimental data of MX-80 bentonite, FEBEX bentonite, and Boom clay 
Table 7 Parameter values of the macrostructural retention model and single porosity retention model for MX-80 bentonite, FEBEX bentonite, and Boom clay

\begin{tabular}{llll}
\hline Parameter & MX-80 bentonite & FEBEX bentonite & Boom clay \\
\hline$\lambda_{\mathrm{s}, \mathrm{M}}$ & 0.904 & 0.381 & 0.906 \\
$\beta_{\mathrm{M}}(\mathrm{MPa})$ & 0.278 & 0.018 & 0.057 \\
$m_{\mathrm{M}}$ & 1.000 & 0.021 & 0.996 \\
$\lambda_{\mathrm{s}}$ & 0.308 & 0.148 & 0.718 \\
$\beta(\mathrm{MPa})$ & 1.066 & 1.186 & 1.903 \\
$m$ & 0.321 & 0.010 & 1.000 \\
\hline
\end{tabular}

calibration is presented as a two-dimensional fit in the $\left(S r_{\mathrm{SPRM}^{-}}{ }^{-}\right)$plane where ${ }^{-}$is the scaled suction defined according to Gallipoli et al. [17] as:

$\bar{s}=s e^{1 / \lambda_{\mathrm{s}}}$ where $e$ is obtained from the experimental data. The resulting parameter values are listed in Table 7 for both the macrostructural retention model and the single porosity retention model, which were obtained applying the least squared method.

To better visualise the results obtained, the comparison of both models with experimental data is also shown in the conventional $S r-s$ space in Fig. 6. In this case, 2D curves cannot be represented, since, for the same value of $s$, different values of $e$ are possible, and vice versa. For Boom clay, since multiple tests were carried out with the same vertical load and initial dry density, only one test for each condition is represented for clarity.

The accuracies of the double and single porosity retention models were initially compared by calculating the root-mean-squared errors (RMSE) of the respective predictions of degree of saturation in the previous calibration tests. For MX- 80 bentonite, the RMSE of the double porosity retention model was two times lower than that of (a)

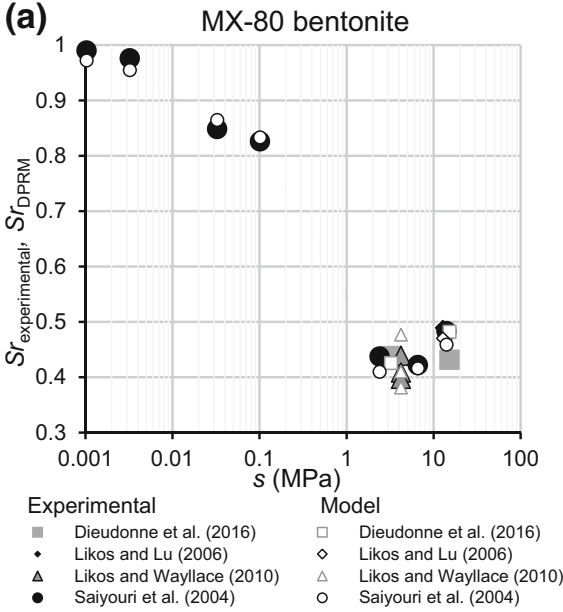

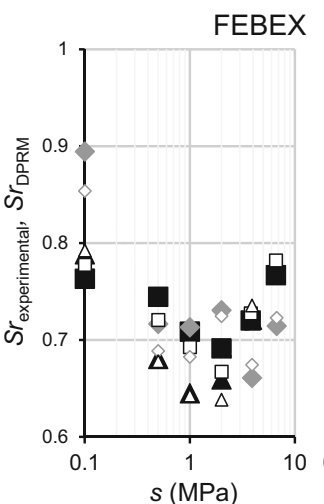

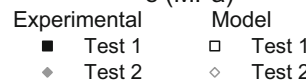

- Test 1

- Test 3 (b)

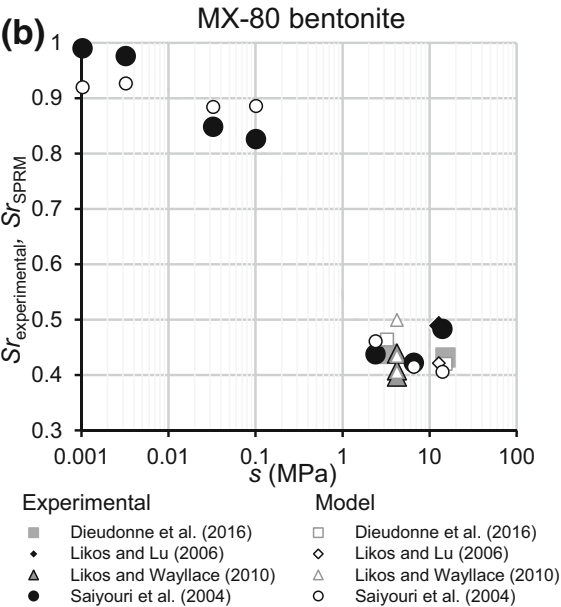

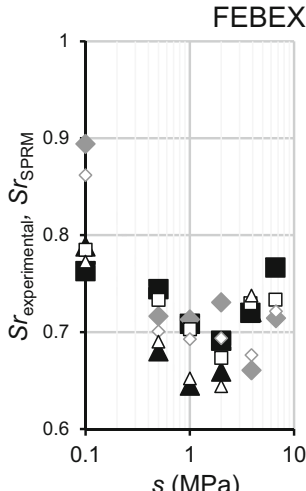

FEBEX bentonite

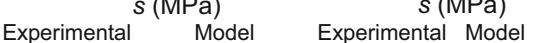

Experimental Model

- Test $1 \quad \square$ Test 1 - Test 4 Test 4

- Test $2 \diamond$ Test $2 \backsim$ Test $5 \square$ Test 5

\ Test $3 \Delta$ Test 3 • Test $6 \diamond$ Test 6

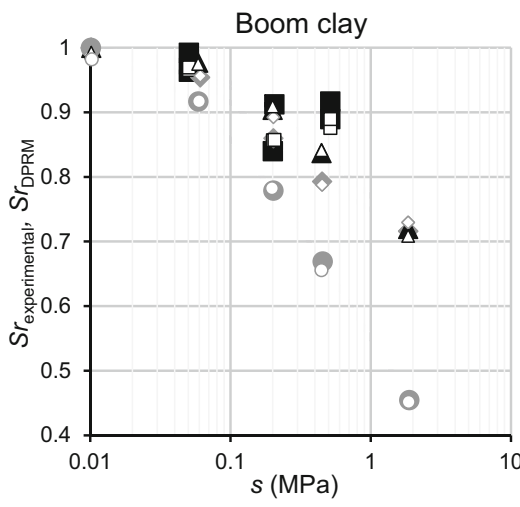

Experimental Model

- Salager et al. (2011) ロ Salager et al. (2011)

- $0.026 \mathrm{MPa}, 1.67 \mathrm{~g} / \mathrm{cm} 3 \quad \diamond \quad 0.26 \mathrm{MPa}, 1.67 \mathrm{~g} / \mathrm{cm} 3$

$\begin{array}{llll}\Delta \quad & 0.55 \mathrm{MPa}, 1.67 \mathrm{~g} / \mathrm{cm} 3 & \Delta & 0.55 \mathrm{MPa}, 1.67 \mathrm{~g} / \mathrm{cm} 3 \\ & 0.6 \mathrm{MPa}, 1.37 \mathrm{~g} / \mathrm{cm} 3 & \circ & 0.6 \mathrm{MPa}, 1.37 \mathrm{~g} / \mathrm{cm} 3\end{array}$

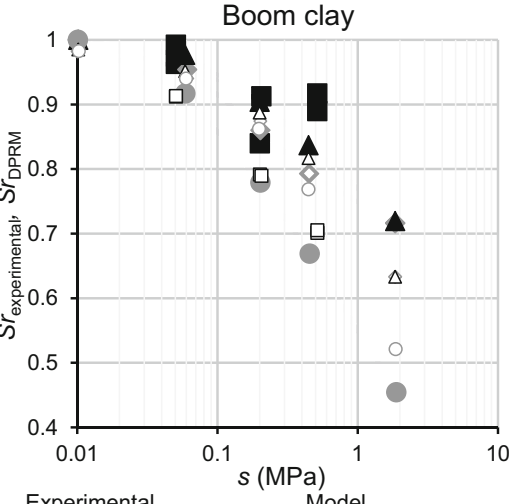

Experimental Model

Salager et al. (2011) $\quad$ - Salager et al. (2011)

$0.026 \mathrm{MPa}, 1.67 \mathrm{~g} / \mathrm{cm} 3 \diamond 0.026 \mathrm{MPa}, 1.67 \mathrm{~g} / \mathrm{cm} 3$ $0.55 \mathrm{MPa}, 1.67 \mathrm{~g} / \mathrm{cm} 3 \quad \Delta \quad 0.55 \mathrm{MPa}, 1.67 \mathrm{~g} / \mathrm{cm} 3$

Fig. 6 Fitting of a double porosity model and $\mathbf{b}$ single porosity model to experimental data of MX-80 bentonite, FEBEX bentonite (tests from Villar [72]) and Boom clay in the $S r-s$ space 

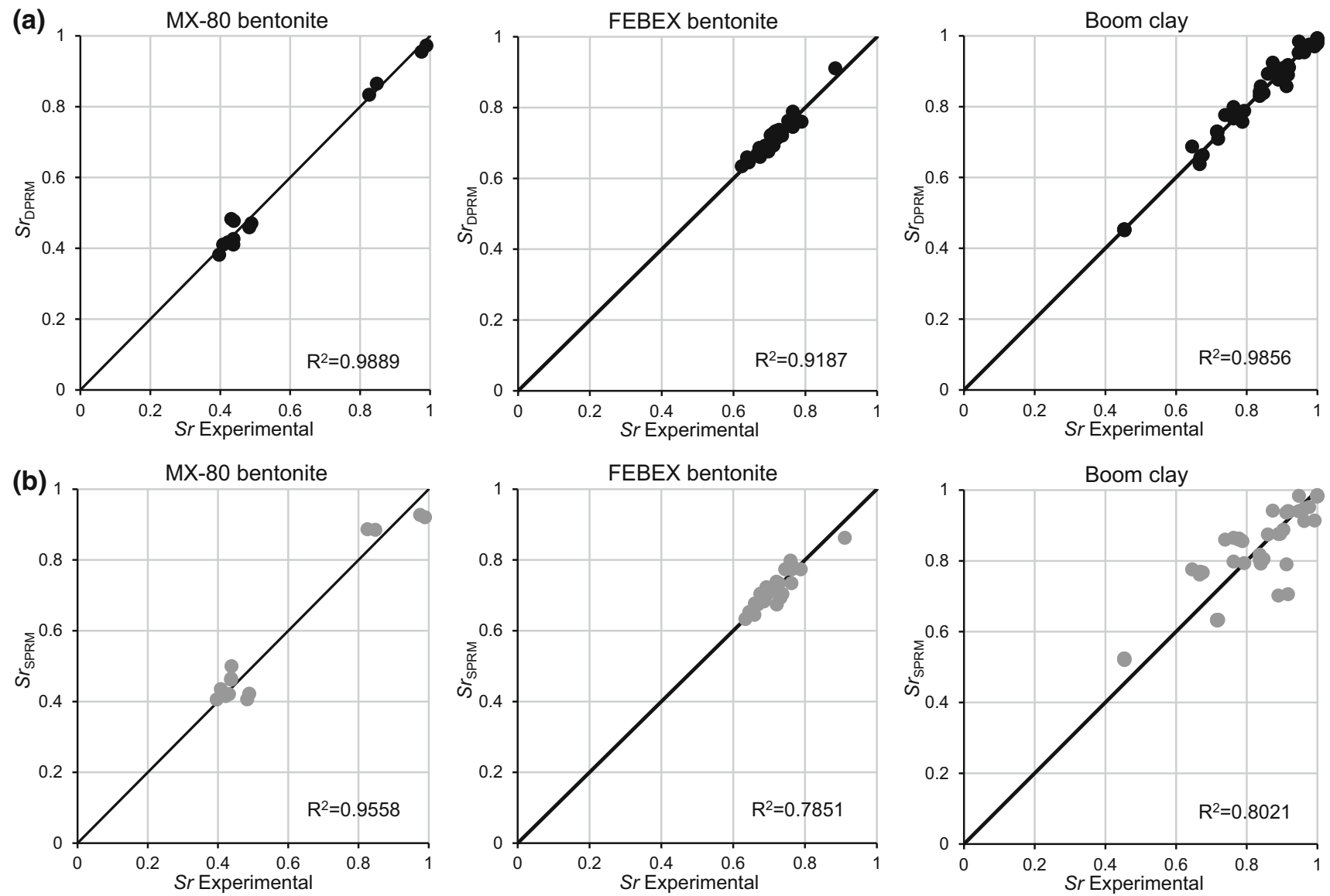

Fig. 7 Experimental versus predicted values of degree of saturation for a the proposed double porosity retention model and $\mathbf{b}$ the original single porosity retention model (calibration data)

the single porosity retention model, i.e. 0.024 against 0.047. For FEBEX bentonite, the double porosity retention model yielded a RMSE of 0.015 , while the single porosity retention model produced a RMSE of 0.024 , i.e. a gain in accuracy of 1.6 times in the former model. Finally, for Boom clay, the RMSE was 0.019 for the double porosity retention model against 0.072 for the single porosity retention model, corresponding to a gain of accuracy of 3.7 times in the former model. The accuracy of both models is graphically shown in Fig. 7, which shows the higher correlation of the double porosity model with the experimental degree of saturation data.

\section{Model validation}

Although the results in the previous section are satisfactory, they do not demonstrate the improved predictive capabilities of the double porosity model, as they are based on the same experimental data employed during calibration of parameter values. For this reason, a validation exercise was carried out where additional data not used during calibration were employed for FEBEX bentonite and Boom clay. Therefore, the same parameters obtained in the calibration were used here. In particular, this additional validation used the free swelling tests on FEBEX bentonite by Lloret and Villar [33], Lloret et al. [34], Pintado [47] and Villar [73] and the constant load wetting tests (with vertical loads of 0.085 and $0.3 \mathrm{MPa}$ ) on Boom clay by Romero [51]. Figure 8 compares the predicted degree of saturation versus scaled suction for both the double and single porosity models against the corresponding experimental data.

Figure 9 plots the same results obtained with the double and the single porosity models in the $S r-s$ space to make the comparison easier. Only one test for each vertical load is represented again for Boom clay. Inspection of Figs. 8 and 9 indicates that the double porosity retention model provides a more accurate prediction of the degree of saturation compared to the single porosity one. For the FEBEX bentonite, the double porosity retention model yields a RMSE of 0.016 , while the single porosity retention model produces a RMSE of 0.027 , i.e. a gain in accuracy of 1.7 times in the former model. The gain in accuracy 

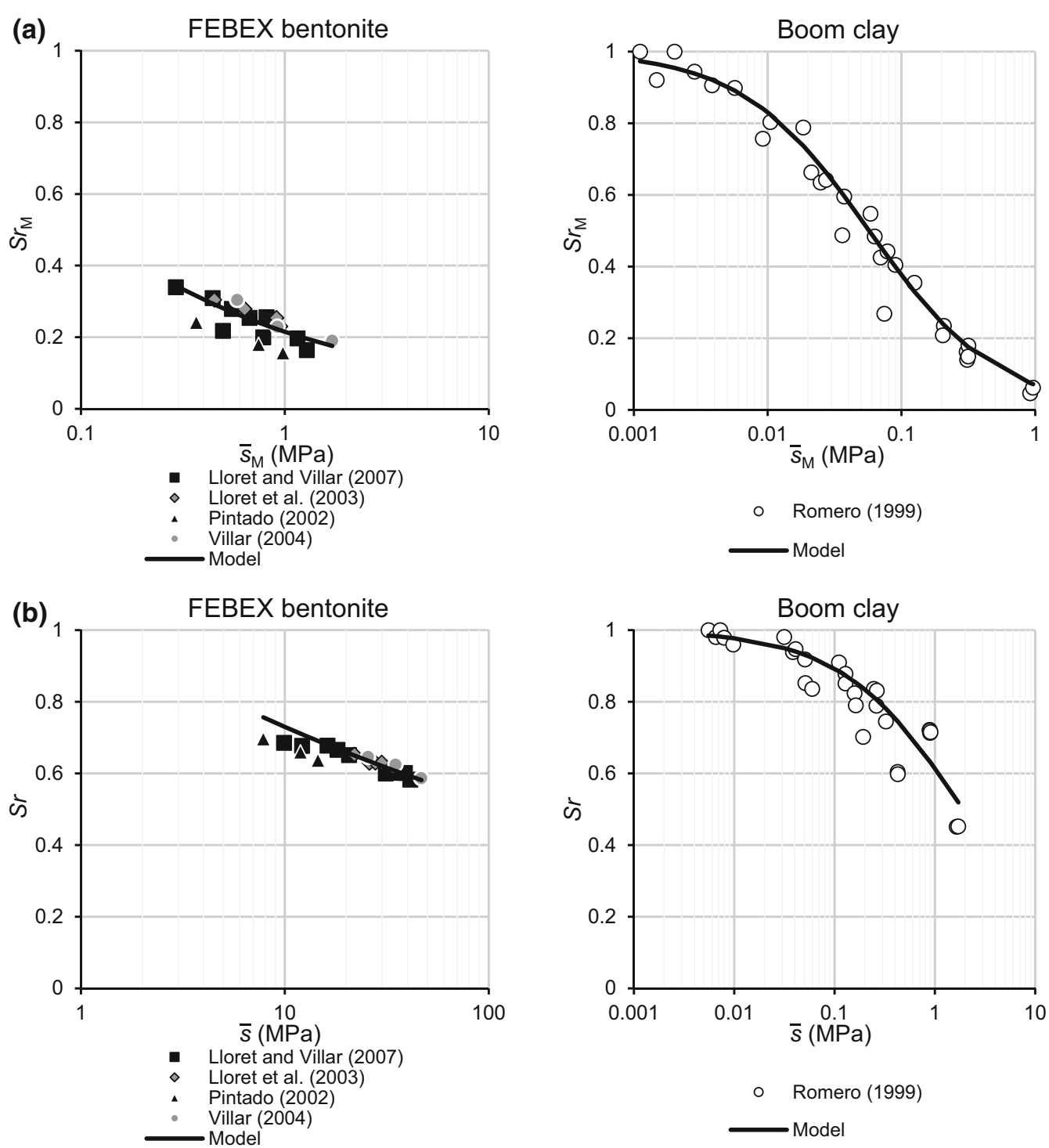

Fig. 8 Validation of a macrostructural retention model and $\mathbf{b}$ single porosity retention model against data of FEBEX bentonite and Boom clay

associated with the use of the double porosity model is similar, even a little greater, to that observed for the calibration data. Similar results were obtained in the case of Boom clay with a RMSE of 0.016 for the double porosity model compared to 0.065 for the single porosity model, i.e. a gain in accuracy of 4.1 times in the former model. It is interesting to note that the model is particularly efficient for not very low suction values, where the sample is not completely saturated and the differences between both models are higher. These can be clearly seen for Boom clay. On the other hand, when the macrostructure is saturated, both models give similar results.

Figure 10 provides a complementary representation of the accuracy of the double and single porosity retention models by plotting their respective predictions of degree of saturation against the corresponding experimental values.
This figure illustrates that the double porosity predictions lie significantly closer to the 1:1 line compared to single porosity predictions for both FEBEX bentonite and Boom clay. This is confirmed by the higher $R^{2}$ values obtained.

\section{Conclusions}

This paper has presented a model to predict the retention behaviour of compacted clays with a double porosity structure consisting of micropores inside clay aggregates and macropores between clay aggregates. The model calculates the degree of saturation by explicitly considering the different retention mechanisms that occur at the microstructural and macrostructural scales. The approach relies on a new formulation that describes the effect of 

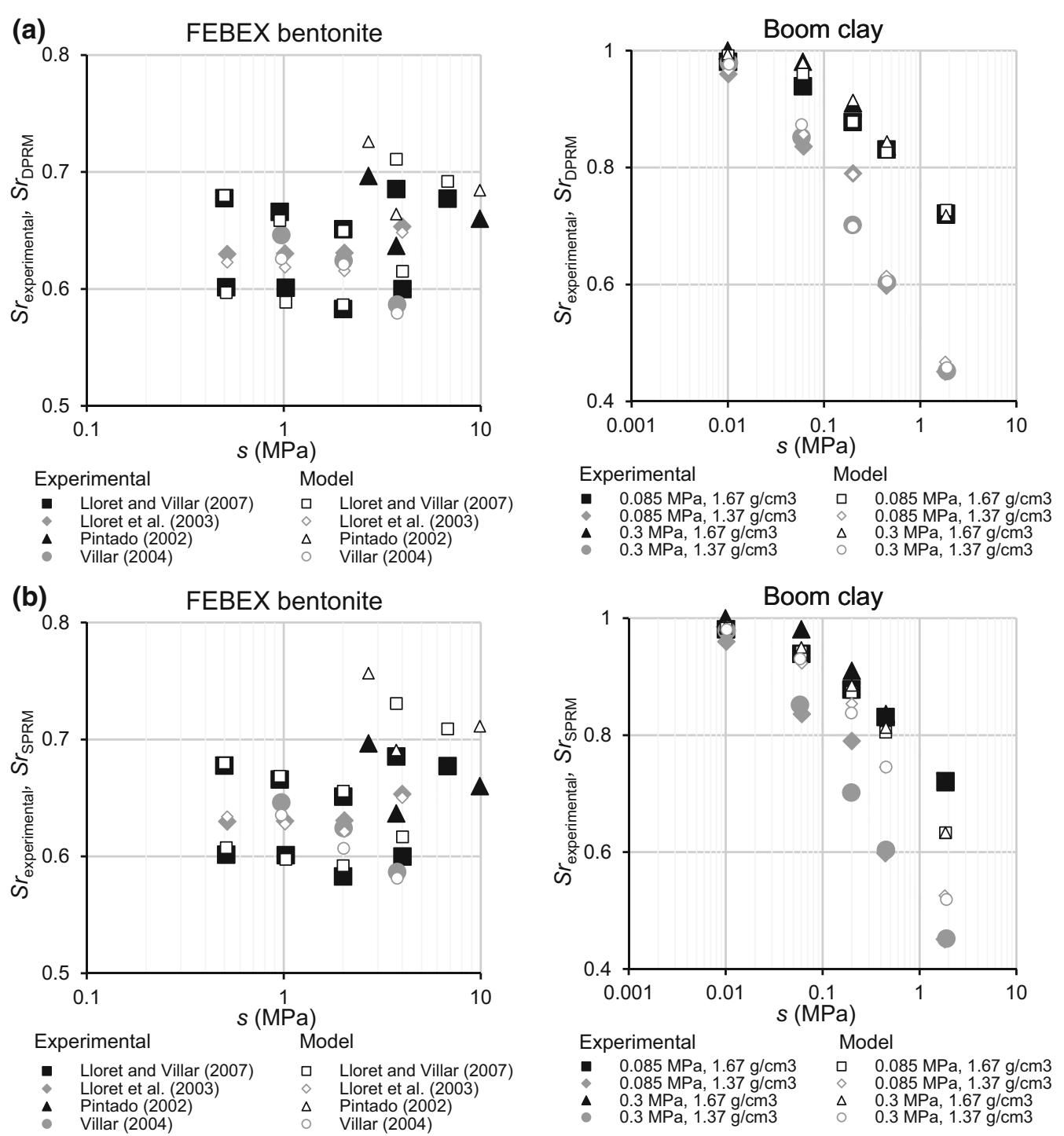

Fig. 9 Validation of $\mathbf{a}$ double porosity retention model and $\mathbf{b}$ single porosity retention model against experimental data of MX-80 bentonite, FEBEX bentonite, and Boom clay in the $S r-s$ space

macrostructural volume changes on the variation in the degree of saturation of the soil. The formulation integrates the simulations of the distinct retention mechanisms within macropores and micropores while accounting for the effect of the volumetric deformation at separate porosity scales. The model requires the definition of three main components: (a) a swelling law for the saturated microstructure, (b) a criterion to assess the presence of water inside the macrostructure and (c) a retention law for the deformable unsaturated macrostructure. In particular, the retention behaviour of the deformable macrostructure was modelled by adapting a previously proposed law for predicting the variation in saturation in single porosity deformable soils.

A review of the existing literature was conducted to collect a considerable amount of data from wetting tests on compacted MX-80 bentonite, FEBEX bentonite, and Boom clay under free swelling, constant load and confined conditions. The collected data were used to formulate, calibrate and validate the proposed double porosity retention model. In particular, part of the experimental data were used to calibrate the model parameters, while the rest of the data were employed to validate the calibrated model. Predictions from the proposed double porosity retention model were also compared with those of an existing single porosity retention model for deformable soils. This comparison confirmed that the explicit consideration of volumetric deformations at different structural scales significantly improves the accuracy of the prediction of degree of saturation in compacted clays.

Acknowledgements The present study was partly funded by an FPU Grant (FPU15/02655) from the Spanish Ministry of Education and a Mobility FPU Grant (EST18/00032) from the Spanish Ministry of 

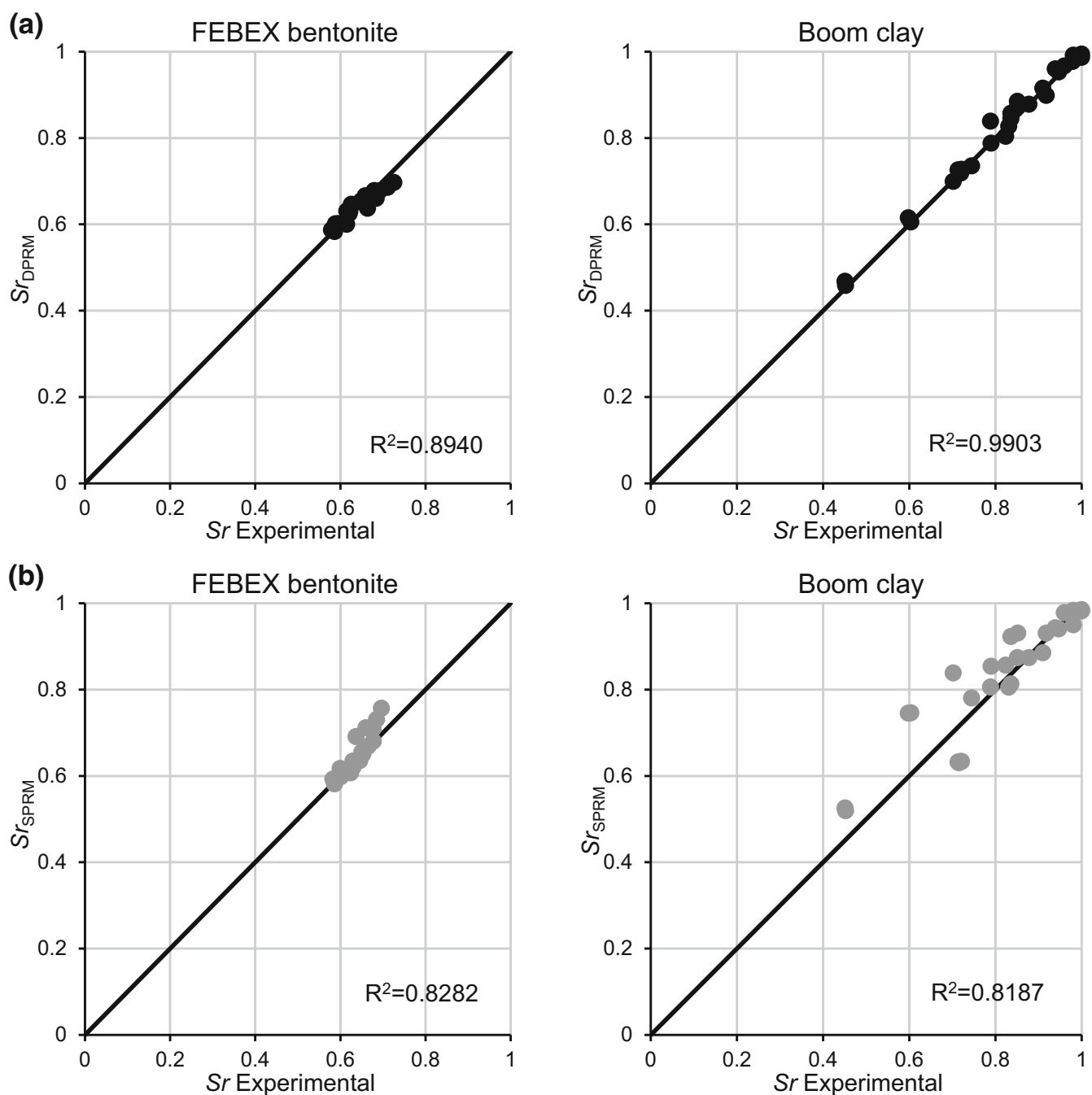

Fig. 10 Experimental versus predicted values of degree of saturation for $\mathbf{a}$ the proposed double porosity model and $\mathbf{b}$ the original single porosity model

Science, Innovation and Universities, both awarded to Ms. De la Morena. The authors also acknowledge the support of the Université de Pau et des Pays de l'Adour, France, for hosting Ms. De la Morena during the visit in which this research was undertaken.

Open Access This article is licensed under a Creative Commons Attribution 4.0 International License, which permits use, sharing, adaptation, distribution and reproduction in any medium or format, as long as you give appropriate credit to the original author(s) and the source, provide a link to the Creative Commons licence, and indicate if changes were made. The images or other third party material in this article are included in the article's Creative Commons licence, unless indicated otherwise in a credit line to the material. If material is not included in the article's Creative Commons licence and your intended use is not permitted by statutory regulation or exceeds the permitted use, you will need to obtain permission directly from the copyright holder. To view a copy of this licence, visit http://creativecommons. org/licenses/by/4.0/.

Funding Open access funding provided by Università degli Studi di Genova within the CRUI-CARE Agreement.

\section{References}

1. Alonso EE, Vaunat J, Gens A (1999) Modelling the mechanical behaviour of expansive clays. Eng Geol 54(1-2):173-183. https:// doi.org/10.1016/S0013-7952(99)00079-4

2. Borja RI, Choo J (2016) Cam-Clay plasticity, Part VIII: a constitutive framework for porous materials with evolving internal structure. Comput Method Appl Mech Eng 309:653-679. https:// doi.org/10.1016/j.cma.2016.06.016

3. Brooks RM, Corey AT (1964) Hydraulic properties of porous media. Hydrology Paper No. 3. Colorado State University, Fort Collins, Colorado, USA.

4. Cases JM, Bérend I, Besson G, François M, Uriot JP, Thomas F, Poirier JE (1992) Mechanism of adsorption and desorption of water vapor by homoionic montmorillonite. 1. The sodium-exchanged form. Langmuir 8(11):2730-2739. https://doi.org/10. 1021/la00047a025.

5. De la Morena G, Asensio L, Navarro V (2018) Intra-aggregate water content and void ratio model for MX-80 bentonites. Eng Geol 246:131-138. https://doi.org/10.1016/j.enggeo.2018.09.028 
6. Delage P, Audiguier M, Cui YJ, Howat MD (1996) Microstructure of a compacted silt. Can Geotech J 33(1):150-158. https:// doi.org/10.1139/t96-030

7. Delage P, Marcial D, Cui YJ, Ruiz X (2006) Ageing effects in a compacted bentonite: a microstructure approach. Géotechnique 56(5):291-304. https://doi.org/10.1680/geot.2006.56.5.291

8. Della Vecchia G, Dieudonné AC, Jommi C, Charlier R (2015) Accounting for evolving pore size distribution in water retention models for compacted clays. Int J Numer Anal Method Geomech 39(7):702-723. https://doi.org/10.1002/nag.2326

9. Della Vecchia G, Jommi C, Romero E (2013) A fully coupled elastic-plastic hydromechanical model for compacted soils accounting for clay activity. Int J Numer Anal Method Geomech 37:503-535. https://doi.org/10.1002/nag.1116

10. Dieudonné AC, Della Vecchia G, Charlier R (2017) Water retention model for compacted bentonites. Can Geotech J 54:915-925. https://doi.org/10.1139/cgj-2016-0297

11. Dieudonné AC, Gatabin C, Talandier J, Collin F, Charlier R (2016) Water retention behaviour of compacted bentonites: experimental observations and constitutive model. E-UNSAT 2016, E3S Web of Conferences, Vol. 9, p. 11012. https://doi.org/ 10.1051/e3sconf/20160911012.

12. Dueck A, Börgesson L (2007) Model suggested for an important part of the hydro-mechanical behaviour of a water unsaturated bentonite. Eng Geol 92(3-4):160-169. https://doi.org/10.1016/j. enggeo.2007.04.004

13. Edlefsen NE, Anderson ABC (1943) Thermodynamics of soil moisture. Hilgardia 15(2):31-298

14. ENRESA (2000) FEBEX Project. Full-scale engineered barriers experiment for a deep geological repository for high level radioactive waste in crystalline host rock. Final Report. Madrid, Spain: ENRESA. https://inis.iaea.org/collection/NCLCollection Store/_Public/31/033/31033797.pdf?r=1\&r=1. Accessed 16 October 2020.

15. Fredlund DG, Xing AQ (1994) Equations for the soil-water characteristic curve. Can Geotech J 31(4):521-532. https://doi. org/10.1139/t94-061

16. Gallipoli D (2010) A hysteretic soil-water retention model accounting for cyclic variations of suction and void ratio. Géotechnique 62(7):605-616. https://doi.org/10.1680/geot.11.P. 007

17. Gallipoli D, Bruno AW, D’Onza F, Mancuso C (2015) A bounding surface hysteretic water retention model for deformable soils. Géotechnique 65(10):793-804. https://doi.org/10.1680/ jgeot.14.P.118

18. Gallipoli D, Wheeler SJ, Karstunen M (2003) Modelling the variation of degree of saturation in a deformable unsaturated soil. Géotechnique 53(1):105-112. https://doi.org/10.1680/geot.2003. 53.1.105

19. Gens A, Alonso EE (1992) A framework for the behaviour of unsaturated expansive clays. Can Geotech J 29(6):1013-1032. https://doi.org/10.1139/t92-120

20. Guimarães LDN, Gens A, Sánchez M, Olivella S (2013) A chemo-mechanical constitutive model accounting for cation exchange in expansive clays. Géotechnique 63(3):221-234. https://doi.org/10.1680/geot.SIP13.P.012

21. Hu R, Chen YF, Liu HH, Zhou CB (2013) A water retention curve and unsaturated hydraulic conductivity model for deformable soils: consideration of the change of pore-size distribution. Géotechnique 63(16):1389-1405. https://doi.org/10.1680/geot. 12.P.182

22. Huyghe JM, Nikooee E, Hassanizadeh SM (2017) Bridging effective stress and soil water retention equations in deforming unsaturated porous media: a thermodynamic approach. Transp Porous Media 117(3):349-365. https://doi.org/10.1007/s11242017-0837-9
23. Iyer KKR, Shetty R, Joseph J, Singh DN (2019) Influence of microstructure on drying- and wetting-characteristics of finegrained soils. Geomech Geoeng 14(4):271-284. https://doi.org/ 10.1080/17486025.2019.1597283

24. Jacinto AC (2010) Thermo-hydro-mechanical behaviour of expansive clays under high temperatures. Application to the Temperature Buffer Test Project. PhD Thesis. Universitat Politècnica de Catalunya, Barcelona, Spain.

25. Jacinto AC, Villar MV, Gómez-Espina R, Ledesma A (2009) Adaptation of the van Genuchten expression to the effects of temperature and density for compacted bentonites. Appl Clay Sci 42:575-582. https://doi.org/10.1016/j.clay.2008.04.001

26. Jacinto AC, Villar MV, Ledesma A (2012) Influence of water density on the water-retention curve of expansive clays. Géotechnique 62(8):657-667. https://doi.org/10.1680/geot.7. 00127

27. Khalili N, Habte MA, Zargarbashi S (2008) A fully coupled flow deformation model for cyclic analysis of unsaturated soils including hydraulic and mechanical hysteresis. Comput Geotech 35(6):872-889. https://doi.org/10.1016/j.compgeo.2008.08.003

28. Kiviranta L, Kumpulainen S (2011) Quality control and characterization of bentonite materials. Posiva Working Report 2011-84. Olkiluoto, Eurajoki, Finland: Posiva Oy. http://www. posiva.fi/files/1994/WR_2011-84_web.pdf. Accessed 16 October 2020.

29. Kuusela-Lahtinen A, Sinnathamby G, Mendez J, Sołowski WT, Gallipoli D, Pintado X, Korkiala-Tanttu LK (2016) Estimation of water retention behaviour of MX-80 bentonite partially saturated with saline solution. UNSAT 2016, E3S Web of Conferences, Vol. 9, p. 11006

30. Lemaire T, Moyne C, Stemmelen D (2004) Imbibition test in a clay powder (MX-80 bentonite). Appl Clay Sci 26(1-4):235-248. https://doi.org/10.1016/j.clay.2003.12.009

31. Likos WJ, Lu N (2006) Pore-scale analysis of bulk volume change from crystalline interlayer swelling in $\mathrm{Na}+-$ and $\mathrm{Ca} 2+-$ smectite. Clay Clay Miner 54(4):516-529. https://doi.org/10. 1346/CCMN.2006.0540412

32. Likos WJ, Wayllace A (2010) Porosity evolution of free and confined bentonites during interlayer hydration. Clay Clay Miner 58(3):399-414. https://doi.org/10.1346/CCMN.2010.0580310

33. Lloret A, Villar MV (2007) Advances on the knowledge of the thermo-hydro-mechanical behaviour of heavily compacted "FEBEX" bentonite. Phys Chem Earth 32:701-715. https://doi. org/10.1016/j.pce.2006.03.002

34. Lloret A, Villar MV, Sánchez M, Gens A, Pintado X, Alonso EE (2003) Mechanical behaviour of heavily compacted bentonite under high suction changes. Géotechnique 53(1):27-40. https:// doi.org/10.1680/geot.2003.53.1.27

35. Low PF, Anderson DM (1958) Osmotic pressure equations for determining thermodynamic properties of soil water. Soil Sci 86(5):251-253. https://doi.org/10.1097/00010694-19581100000004

36. Man A, Martino JB (2009) Thermal, Hydraulic and Mechanical Properties of Sealing Materials. NWMO TR-2009-20. Toronto, Ontario, Canada: Nuclear Waste Management Organization. https://www.nwmo.ca/ /media/Site/Reports/2015/09/22/05/22/ 1769_nwmotr-2009-20thmproperties_r0f.ashx?la=en. Accessed 16 October 2020.

37. Masin D (2010) Predicting the dependency of a degree of saturation on void ratio and suction using effective stress principle for unsaturated soils. Int J Anal Method Geomech 34(1):73-90. https://doi.org/10.1002/nag. 808

38. Musso G, Romero E, Della Vecchia G (2013) Double-structure effects on the chemo-hydro-mechanical behaviour of a compacted active clay. Géotechnique 63(3):206-220. https://doi.org/ 10.1680/geot.SIP13.P.011 
39. Na WS (2017) Distinguishing crack damage from debonding damage of glass fiber reinforced polymer plate using a piezoelectric transducer based nondestructive testing method. Compos Struct 159:517-527. https://doi.org/10.1016/j.compstruct.2016. 10.005

40. Navarro V, Asensio L, De la Morena G, Pintado X, Yustres Á (2015) Differentiated intra- and inter-aggregate water content models of mx-80 bentonite. Appl Clay Sci 118:325-336. https:// doi.org/10.1016/j.clay.2015.10.015

41. Navarro V, De la Morena G, González-Arteaga J, Yustres Á, Asensio L (2018) A microstructural effective stress definition for compacted active clays. Geomech Energy Environ 15:47-53. https://doi.org/10.1016/j.gete.2017.11.003

42. Navarro V, Yustres Á, Asensio L, De la Morena G, GonzálezArteaga J, Laurila T, Pintado X (2017) Modelling of compacted bentonite swelling accounting for salinity effects. Eng Geol 223:48-58. https://doi.org/10.1016/j.enggeo.2017.04.016

43. Newman ACD (1983) The specific surface of soils determined by water sorption. J Soil Sci 34(1):23-32. https://doi.org/10.1111/j. 1365-2389.1983.tb00809.x

44. Nowamooz H, Mrad M, Abdallah A, Masrouri F (2009) Experimental and numerical studies of the hydromechanical behaviour of a natural unsaturated swelling soil. Can Geotech J 46(4):393-410. https://doi.org/10.1139/T08-127

45. Nuth M, Laloui L (2008) Advances in modelling hysteretic water retention curve in deformable soils. Comput Geotech 35(6):835-844. https://doi.org/10.1016/j.compgeo.2008.08.001

46. Or D, Tuller M (1999) Liquid retention and interfacial area in variably saturated porous media: upscaling from single-pore to sample-scale model. Water Resour Res 35(12):3591-3605. https://doi.org/10.1029/1999WR900262

47. Pintado X (2002) Caracterización del comportamiento TermoHidro-Mecánico de arcillas expansivas. PhD Thesis. Universitat Politècnica de Catalunya, Barcelona, Spain.

48. Pintado X, Rautioaho E (2013) Thermo-Hydraulic modelling of buffer and backfill. Posiva Report 2012-48. Olkiluoto, Eurajoki, Finland: Posiva Oy. http://www.posiva.fi/files/3351/POSIVA 2012-48.pdf. Accessed 16 October 2020.

49. Pintado X, Mamunul HM, Martikainen J (2013) Thermo-HydroMechanical tests of buffer material. Posiva 2012-49. Olkiluoto, Eurajoki, Finland: Posiva Oy. http://www.posiva.fi/files/3385/ POSIVA_2012-49.pdf. Accessed 16 October 2020.

50. Rinnert E, Carteret C, Humbert B, Fragneto-Cusani G, Ramsay JDF, Delville A, Robert JL, Bihannic I, Pelletier M, Michot LJ (2005) Hydration of a synthetic clay with tetrahedral charges: a multidisciplinary experimental and numerical study. J Phys Chem B 109(49):23745-23759. https://doi.org/10.1021/jp050957u

51. Romero E (1999) Characterisation and Thermo-Hydro-Mechanical behaviour of unsaturated Boom clay: an experimental study. $\mathrm{PhD}$ Thesis. Universitat Politècnica de Catalunya, Barcelona, Spain.

52. Romero E, Della Vecchia G, Jommi C (2011) An insight into the water retention properties of compacted clayey soils. Géotechnique 61(4):313-328. https://doi.org/10.1680/geot.2011.61.4.313

53. Romero E, Gens A, Lloret A (1999) Water permeability, water retention and microstructure of unsaturated compacted Boom clay. Eng Geol 54(1-2):117-127. https://doi.org/10.1016/S00137952(99)00067-8

54. Rostami A, Habibagahi G, Ajdari M, Nikooee E (2015) Pore network investigation on hysteresis phenomena and influence of stress state on the SWRC. Int J Geomech 15(5):04014072. https:// doi.org/10.1061/(ASCE)GM.1943-5622.0000315

55. Saiyouri N, Tessier D, Hichier PY (2004) Experimental study of swelling in unsaturated compacted clays. Clay Miner 39:469-479. https://doi.org/10.1180/0009855043940148
56. Salager S, Rizzi M, Laloui L (2011) An innovative device for determining the soil water retention curve under high suction at different temperatures. Acta Geotech 6:135-142. https://doi.org/ 10.1007/s11440-011-0141-8

57. Salager S, Youssoufi MS, Saix C (2010) Definition and experimental determination of a soil-water retention surface. Can Geotech J 47(6):609-622. https://doi.org/10.1139/T09-123

58. Salles F, Douillard JM, Denoyel R, Bildstein O, Jullien M, Beurroies I, Van Damme H (2009) Hydration sequence of swelling clays: evolutions of specific surface area and hydration energy. J Colloid Interface Sci 333(2):510-522. https://doi.org/ 10.1016/j.jcis.2009.02.018

59. Sánchez M, Gens A, Guimarães LDN, Olivella S (2005) A double structure generalized plasticity model for expansive materials. Int J Numer Anal Method Geomech 29(8):751-787. https://doi.org/ 10.1002/nag. 434

60. Sanjuan B, Mossmann JR, Merceron T (1994) Modelling boom clay formation porewater chemistry: ion exchange versus dissolution precipitation mechanisms. Goldschmidt Conference Edinburgh, pp 801-802.

61. Sedighi M, Thomas HR (2014) Micro porosity evolution in compacted swelling clays-a chemical approach. Appl Clay Sci 101:608-618. https://doi.org/10.1016/j.clay.2014.09.027.

62. Seiphoori A, Ferrari A, Laloui L (2014) Water retention behaviour and microstructural evolution of MX-80 bentonite during wetting and drying cycles. Géotechnique 64(9):721-734. https:// doi.org/10.1680/geot.14.P.017

63. Song X, Borja RI (2014) Mathematical framework for unsaturated flow in the finite deformation range. Int $\mathrm{J}$ Numer Method Eng 97:658-682. https://doi.org/10.1002/nme.4605

64. Stepkowska ET, Pérez-Rodríguez JL, Maqueda C, Starnawska E (2004) Variability in water sorption and in particle thickness of standard smectites. Appl Clay Sci 24(3-4):185-199. https://doi. org/10.1016/j.clay.2003.03.004

65. Sun DA, Sheng D, Xiang L, Sloan SW (2008) Elastoplastic prediction of hydro-mechanical behaviour of unsaturated soils under undrained conditions. Comput Geotech 35(6):845-852. https://doi.org/10.1016/j.compgeo.2008.08.002

66. Tang AM, Cui YJ (2010) Effects of mineralogy on thermo-hydromechanical parameters of MX80 bentonite. J Rock Mech Geotech Eng 2(1):91-96. https://doi.org/10.3724/SP.J.1235.2010. 00091

67. Tarantino A (2009) A water retention model for deformable soils. Géotecnique 59(9):751-762. https://doi.org/10.1680/geot.7. 00118

68. Tavakoli Dastjerdi MH, Habibagahi G, Nikooee E (2014) Effect of confining stress on soil water retention curve and its impact on the shear strength of unsaturated soils. Vadose Zone J 13(5):1-11. https://doi.org/10.2136/vzj2013.05.0094

69. Torres R, Dietrich WE, Montgomery DR, Anderson SP, Loague K (1998) Unsaturated zone processes and the hydrologic response of a steep, unchanneled catchment. Water Resour Res 34(8):1865-1879. https://doi.org/10.1029/98WR01140

70. van Genuchten MT (1980) A closed-form equation for predicting the hydraulic conductivity of unsaturated soils. Soil Sci Soc Am J 44(5):892-898. https://doi.org/10.2136/sssaj1980. $03615995004400050002 x$

71. Vaunat J, Gens A (2005) Analysis of the hydration of a bentonite seal in a deep radioactive waste repository. Eng Geol 81:317-328. https://doi.org/10.1016/j.enggeo.2005.06.014

72. Villar MV (2002) Thermo-hydro-mechanical characterisation of a bentonite from Cabo de Gata. A study applied to the use of bentonite as sealing material in high level radioactive waste repositories. Publicación Técnica ENRESA, Madrid, Spain

73. Villar MV (2004) Thermo-Hydro-Mechanical characteristics and processes in the clay barrier of a high level radioactive waste 
repository. State of the Art Report. Publicación Técnica ENRESA, Madrid, Spain.

74. Villar MV (2007) Water retention of two natural compacted bentonites. Clay Clay Miner 55(3):311-322. https://doi.org/10. 1346/CCMN.2007.0550307

75. Villar MV, Sánchez M, Gens A (2008) Behaviour of a bentonite barrier in the laboratory: experimental results up to 8 years and numerical simulation. Phys Chem Earth 33:S476-S485. https:// doi.org/10.1016/j.pce.2008.10.055
76. Woodruff WF, Revil A (2011) CEC-normalized clay-water sorption isotherm. Water Resour Res. 47(11). https://doi.org/10. 1029/2011WR010919.

77. Yong RN (1999) Soil suction and soil-water potentials in swelling clays in engineered clay barriers. Eng Geol 54(1-2):3-13. https://doi.org/10.1016/S0013-7952(99)00056-3

Publisher's Note Springer Nature remains neutral with regard to jurisdictional claims in published maps and institutional affiliations. 